\title{
EXPERIENCE WITH BURROWING OWL NEST-BOXES IN SASKATCHEWAN, WITH COMMENT ON DECREASING RANGE
}

C. STUART HOUSTON, 863 University Drive, Saskatoon, SK. S7N 0J8; DALE G. HJERTAAS, 15 Olson Place, Regina, SK. S4S 2J6; R. LORNE SCOTT, Box 995, Indian Head, SK. SOG 2K0; and PAUL C. JAMES, Department of Environment and Resource Management, 3211 Albert St., Regina, SK. S4S 5W6

Numbers of the attractive, longlegged little Burrowing Owl, Speotyto cunicularia, have been declining continuously in Saskatchewan for about 20 years. We wish to share our experiences, both successful and unsuccessful, in supplying nest-boxes in an attempt to help them.

\section{Saskatchewan Nest-box Successes}

The Saskatchewan success story began in 1983 when a golf driving range, constructed near the Heritage Inn in Moose Jaw, posed a threat to a colony of Burrowing Owls. While cultivating and levelling the land for this new purpose, the owners inadvertently filled in the entrance to an underground Burrowing Owl nesthole. Although the young owls were already making forays out of this hole, they kept returning to the filledin entrance. George Davies noticed the predicament of the owls and reopened the hole, only to have it filled in again. George and his friend, Hugh Somers, both members of the South Saskatchewan Wildlife Association, again opened the hole, put yellow stakes around it, and notified the driving range manager who was apologetic for failing to notice the presence of the owls. The owls immediately returned to the hole and used the stakes as hunting perches.
George learned of Burrowing Owl box projects in California, and wrote to obtain Collins-Landry plans from the Department of Natural Resources in Sacramento. ${ }^{2}$ George and Hugh constructed two boxes and placed them in safe spots about $60 \mathrm{~m}$ from the threatened nest. Within hours the burrowing owls inspected these new accommodations.

Encouraged, George and Hugh placed nest boxes on the adjacent Lynbrook Golf Course, where George was an active member. Owls were nesting there in natural holes on the fifth fairway. Two nest-boxes were placed in the rough, and in the late fall the natural holes on the fairway were filled in. In the spring of 1984 owls moved into the nestboxes.

Each nest-box had a screwed-on roof and was placed near the surface under a square of easily lifted sod, thus allowing easy access for banding young - not possible in natural badger holes where the owl young are often $1 \mathrm{~m}$ below the surface. One of us (Scott) began banding young Burrowing Owls in the Moose Jaw nest boxes in 1984 .

The Saskatchewan Natural History 
Society was quick to recognize the ground-breaking (!) achievements of George Davies, who was awarded, in absentia, with the society's Conservation Award for 1984 at the annual meeting in Melfort that year. ${ }^{9}$

In 1985, Grant and Sheila Fahlman, farmers near Kronau, 25 $\mathrm{km}$ east-southeast of Regina, were planning to sell their cattle and break the pasture for growing wheat. Lorne Scott and Dale Hjertaas, recognizing the importance of the colony of Burrowing Owls on the Fahlman pasture, arranged for payment of an annual fee to maintain the land as pasture with its owl habitat; financial assistance came from the World Wildlife Fund of Canada. This was the first-ever organizational agreement in Saskatchewan to protect a Burrowing Owl nest site. ${ }^{11}$ In August 1985, Hjertaas and Scott installed 12 nest-boxes on this pasture.

Each year, most Burrowing Owls used boxes instead of the natural badger holes and fledged at least an average number of young per nest; a wooden, right-angle tunnel made access more difficult for predatory badgers and foxes.

The Fahlman pasture was an ideal site for H.R.H. Prince Philip, on tour with the World Wildlife Fund, to visit on 4 June 1987, when the first young owls of the season were just big enough to band; an event covered by national media. This was the day before the official ceremony at Last Mountain Lake, celebrating the 100th anniversary of North America's first migratory bird sanctuary. ${ }^{13}$

By 1992, there were 126 nestboxes in place at 41 sites. Through 1993, Scott banded 417 nestling Burrowing Owls at Moose Jaw and Kronau. Through 1991, Hjertaas banded 139 nestlings and four adults in boxes in the Avonlea, Milestone and Moose Jaw areas. As yet, there have been no recoveries from the wintering grounds, presumed to be in Texas and/or Mexico.

\section{Saskatchewan Failures}

In 1987, Houston and his crew thought they should try to help a small colony of five pairs of Burrowing Owls that had for several years occupied the south border of the Kindersley-Elna Prairie Farm Rehabilitation Administration (PFRA) pasture, south of Smiley, Saskatchewan. On 25 October, with the permission of Jim Hoffman, pasture manager, six boxes were dug in. A single adult, late to migrate, was still on site. Four boxes were placed, each within $5 \mathrm{~m}$ of a hole occupied earlier that year within the main colony. One was placed on the summit of a small rise $100 \mathrm{~m}$ to the east, and one near a separate occupied hole south of the corral, about $200 \mathrm{~m}$ distant. Patsy Hoffman, Jim's wife, and sons Steve and Michael came to watch David Miller, Stuart and Mary Houston and Dylan von Kuster constructing and digging-in the prefabricated components supplied by Dale Hjertaas of the Department of Natural Resources (now the Department of Environment and Resource Management), Regina. Great was our disappointment when not a single box was occupied in 1988 or subsequent years (although another colony was later located $10 \mathrm{~km}$ farther north, east of the pasture headquarters, with 18 pairs in 1991, 9 pairs in 1992 and 2 pairs in their final year of occupancy, 1993).

In 1988, highway construction unearthed an active Burrowing Owl nest along highway 44 immediately west of Eston. Houston was asked 
for advice and referred the highway crew to Hjertaas. Since a fenced-in Department of Highways' compound was just across the ditch to the south, an artificial box was placed within the compound by Craig Palmer and John Pollock. ${ }^{10}$ Not only did the owls take over care of the young in the new location, but subpermittee Martin Gerard was able to go to Eston on 11 July and band seven healthy young in the box. Martin found a larder of three uneaten deer mice in the box, and hundreds of fleas. Soon thereafter the pair moved their young to a nearby badger hole, and on 25 July one of the adults was killed by a car on Highway 44. The next day, one of the banded young was run over on the same highway, less than $100 \mathrm{~m}$ from the badger hole. This success was short-lived; the Eston pair failed to return in 1989 and subsequent years.

In the fall of 1988, Hjertaas sent Houston prefabricated components for five more boxes. On 9 October, after obtaining permission, two boxes were dug in at the two-pair colony on John and Barb Lypka's pasture, within sight of their home north of Rosetown, and on Stuart Hanson's pasture north of Tessier. On the Lypka pasture a single adult was still present. Our crew was David Miller, Cathryn Miller, Nigel Mathews, Cecily Grant, Dylan von Kuster and Jill Hocken. On 16 October David Miller, Kelly Wylie, Martin and Silvia Gerard, with much help from pasture owner Bert Bentley, dug in two boxes at a two-pair site on the edge of the hamlet of Clavet.

Boy Scouts with Hjertaas similarly dug in ten boxes at the Walter Bedford pasture near Avonlea in 1987; one box was used in 1988, with seven nestlings banded. The remaining boxes were ignored or filled in by ground squirrels. Two boxes near Condie and two near Saskatoon had a similar fate.

The Houston effort of placing nestboxes to help this declining species has come to naught. Not one box has been occupied and no owl pair has returned to use the adjacent active badger hole burrows, which in each case had been in use just months before the installation of artificial boxes. Our best guess is that by chance we chose sites where, for some unknown reason, the owls did not survive their winter migration to and back from Texas or Mexico. Judging from experience at the Walter Bedford farm at Avonlea, ground squirrels may have filled some of the box entrance tunnels with dirt. Since the process has been of help elsewhere, it is difficult to imagine how our intervention could have had any detrimental effect the following season.

\section{Decreasing Range and Numbers North of South Saskatchewan River}

Burrowing Owls have nesting habitat requirements of short grass, open sites, and badger and ground squirrel burrow availability. ${ }^{3}$ In their heyday, Burrowing Owls were known to use much smaller stretches of pasture, including grassy strips along railroad right-of-ways in the midst of otherwise fully cultivated land. Near Eston, in 1960, the late Bill Richards, a railway employee, counted 17 Burrowing Owls along $46 \mathrm{~km}$ of right-ofway radiating in three directions in intensively farmed areas surrounding Eston (pers. comm.). In Saskatchewan, Burrowing Owls once nested sparingly as far north as the parklands and even to the southern edge of the mixed forest. A single pair nested at Livelong, $53^{\circ} 27^{\prime}$ 
North, in $1943,{ }^{12}$ and another pair bred at Nipawin, $53^{\circ} 22^{\prime}$ North, in $1940 .^{6}$ The range is now shrinking, and the numbers are declining. In spite of each owner's care and concern, $68 \%$ of the Operation Burrowing Owl pastures that were occupied in 1986 were unoccupied by 1993.5

Burrowing Owls like to use the edges of large PFRA pastures, where there are fences to perch on - commonly near to roads where some of the young are killed by passing cars, as noted first in the Dakotas by Brenckle in the 1930s. ${ }^{1}$ The long-term use of the nine pastures within the Kindersley 1:250,000 [National Topographical Service] map sheet, $51^{\circ}$ to $52^{\circ}$ and $108^{\circ}$ to $110^{\circ}$, has declined drastically. The northernmost recent site, the Heart's Hill PFRA pasture, 51 55' North, along the Alberta boundary south of Cactus Lake, has not had a breeding pair since 1985. Pasture manager Joe Kohlman notes that the disappearance of the owls coincided with increased use of grasshopper biocides, particularly carbofuran, just outside the pasture, providing anecdotal support to previous studies of the harmful effects of carbofuran. ${ }^{8}$ More surprisingly, not one has been seen in the Antelope Park pasture since about 1980 (Doug Young, pers. comm.).

At the Mantario (four pairs) and Hillsburgh pastures, Burrowing Owls disappeared about 1986 (Paul Moffenbauer and Lise Larson, pers. comm.). At Eagle Lake pasture, north of Netherhill, there were five pairs in 1990, with the last pair seen in 1993 (Ed Koch, pers. comm.). At Newcombe pasture, south of Glidden, in the early 1980s there were three different sites with six, four and three pairs, but none have been present since 1990 (Lloyd Dowd, pers. comm.). At Progress pasture, west of Kerrobert, there were one or two pairs near Beloil Lake until 1993 or 1994, but none since (Bill Meek, pers. comm.). The Mariposa pasture, east of Kerrobert, had a declining population until there was only one pair found in 1993, only an apparently unmated singleton in 1994, one pair in 1995, the year two were found drowned in a water-trough just east of the headquarters (Wendell Roszell, pers. comm.), and one pair in 1996, the only pair located by Houston in any PFRA pasture in 1995 or 1996 . Outside of the government pastures in 1996, a small colony of three pairs persisted south of Plato (Hazel Fors, pers. comm.), one pair near Laporte (Jean Harris, pers. comm.), and a probable pair near Cabri Lake (Dean Francis, pers. comm.).

On the Rosetown map sheet (immediately east of the Kindersley map sheet), where Wedgwood had 25 sites in $1975,{ }^{14}$ at least four sites were active in 1996: three pairs on Harvey Lonsberry's pasture east of Wiseton, a single pair known near Ardath in a pasture locally unusual for its persisting high numbers of Richardson's Ground Squirrels; one pair in a pasture on highway 45 , east of Conquest (Marion Deschamps, pers. comm.), and one pair within a mile west of the Gardiner Dam (Frank Roy, pers. comm.). East of Highway 4, from Rosetown to Kyle, owl numbers were already in decline by $1975 .{ }^{14}$ This decline had accelerated throughout most of southern Saskatchewan by $1992{ }^{7}$ Southwest of Kyle, on the Prelate map sheet, one pair returned to a long-term site on the Tritten pasture in 1996, but apparently raised no young.

Sadly, the provincewide Operation Burrowing Owl program of 
posting and protecting land ${ }^{4}$ has been insufficient to stay the downward trend of this vulnerable species. Local supplemental feeding in an experimental study area (T. Wellicome, pers. comm.) may prove more successful. If the obvious, widespread decline of this interesting species cannot be slowed or even reversed, total extirpation from Saskatchewan may be closer than we care to think.

Acknoẃledgements: Jim Wedgwood kindly provided a breakdown of Burrowing Owl numbers on the east and west sides of the Saskatchewan River. We thank Jim Duncan for constructive criticism.

1. BRENCKLE, J.F. 1936. The migration of the Western Burrowing Owl. BirdBanding 7:166-168.

2. COLLINS, C.T., and LANDRY, R.E. 1977. Artificial nest burrows for Burrowing Owls. North American Bird Bander 2:151-154.

3. HAUG, E.A., and L.W. OLIPHANT. 1990. Movements, activity patterns, and habitat use of Burrowing Owls in Saskatchewan. J. Wildl. Manage. 54: 27-35.

4. HJERTAAS, D.G. 1996. Operation Burrowing Owl in Saskatchewan: the first six years. Proceedings of Burrowing Owl Symposium, Raptor Research Foundation annual meeting, Bellevue, Washington, 13 November 1992. [in press]

5. HOLROYD, G.L. 1995. Conservation of prairie raptors. Transactions of the 60th North American Wildlife Conference: $173-180$.
6. HOUSTON, C.S., and M.G. STREET. 1959. Birds of the Saskatchewan River, Carlton to Cumberland. Saskatchewan Natural History Society, Regina.

7. JAMES, P.C., T.J. ETHIER, and M.K. TOUTLOFF. 1996. Parameters of a declining Burrowing Owl population in Saskatchewan. Proceedings of Burrowing Owl Symposium, Raptor Research Foundation annual meeting, Bellevue, Washington, 13 November 1992. [in press].

8. JAMES, P.C., and G.A. FOX. 1987. Effects of some insecticides on productivity of burrowing owls. Blue Jay 45:65-71.

9. LAMONT, S. 1984. SNHS awards 1984. Blue Jay 42:251.

10. PALMER, C. and J. POLLOCK. 1988. Relocating a Burrowing Owl nest to a nest box. Blue Jay 46:208-211.

11. RABBIOR, G.W., and L.W. SMITH. 1992. Case study: Grant Fahlman and Dale Hjertaas, Operation Burrowing Owl, Saskatchewan. in Entrepreneurship: The Spirit of Adventure. Teacher's Guide: 166-167. Harcourt, Brace, Jovanovich, Toronto.

12. SHAW, W.T. 1944. Extension of breeding range of the Western Burrowing Owl in Saskatchewan. Auk 61:473-474.

13. TAYLOR, P.S. 1987. Wildlife ' 87 : gaining momentum. Blue Jay 45:192195.

14. WEDGWOOD, J.A. 1976. Burrowing owls in south-central Saskatchewan. Blue Jay 34:26-44.

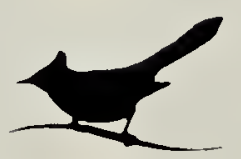

